\title{
Characterization of two antimicrobial peptides produced by a halotolerant Bacillus subtilis strain SK.DU.4 isolated from a rhizosphere soil sample
}

\author{
Piyush Baindara', Santi M Mandal ${ }^{2}$, Niharika Chawla ${ }^{1}$, Pradip Kumar Singh ${ }^{1}$, Anil Kumar Pinnaka
} and Suresh Korpole ${ }^{1 *}$

\begin{abstract}
A bacterial strain producing two antimicrobial peptides was isolated from a rhizosphere soil sample and identified as Bacillus subtilis based on both phenotypic and $16 \mathrm{~S}$ rRNA gene sequence phylogenetic analysis. It grew optimally up to $14 \% \mathrm{NaCl}$ and produced antimicrobial peptide within $24 \mathrm{~h}$ of growth. The peptides were purified using a combination of chemical extraction and chromatographic techniques. The MALDI-TOF analysis of HPLC purified fractions revealed that the strain SK.DU.4 secreted a bacteriocin-like peptide with molecular mass of 5323.9 Da and a surface-active lipopeptide (m/z $1056 \mathrm{Da})$. The peptide mass fingerprinting of low-molecular-weight bacteriocin exhibited significant similarity with stretches of secreted lipoprotein of Methylomicrobium album BG8 and displayed 70\% sequence coverage. MALDI MS/MS analysis elucidated the lipopeptide as a cyclic lipopeptide with a $\beta$-hydroxy fatty acid linked to Ser of a peptide with seven a-amino acids (Asp-Tyr-Asn-GIn-Pro-Asn-Ser) and assigned it to iturin-like group of antimicrobial biosurfactants. However, it differed in amino acid composition with other members of the iturin family. Both peptides were active against Gram-positive bacteria, suggesting that they had an additive effect.
\end{abstract}

Keywords: Bacillus, Antimicrobial peptide, Lipopeptide, Chromatography, RP-HPLC, MALDI

\section{Introduction}

Antimicrobial peptides characterization has received great attention in the recent past due to their applications as food preservatives without any toxic effects on host and therapeutic agents. At present preservation of food is a serious concern for almost all countries across the world. Since lactic acid bacteria (LAB) produce an array of antimicrobial substances they were used as natural bio-preservatives for special applications (Holzapfel et al. 1995; Cotter et al. 2005; Deegan et al. 2006). Other bacteria such as Enterococcus, Streptococcus etc., were also reported to produce various bacteriocins and they are also being considered for different applications. However, production of antimicrobial peptides by Bacillus strains has been increasingly characterized in the recent past and many peptides produced by this group of bacteria found to be

\footnotetext{
* Correspondence: suresh@imtech.res.in

'MTCC and Gene Bank, CSIR-Institute of Microbial Technology, Sector 39A, Chandigarh 160036, India

Full list of author information is available at the end of the article
}

suitable for various applications (Abriouel et al. 2011). The antimicrobial peptides produced by Bacillus spp., includes various classes of bacteriocins (Klaenhammer 1993), antimicrobial surface-active biosurfactants like lipopeptides, glycopeptides and nonribosomally synthesized cyclic peptides (Mukherjee et al. 2006; Rodrigues et al. 2006). Among the antimicrobial biosurfactants, lipopeptides contain peptides with 7-10 amino acid that are cyclised via a lactone ring to a $\beta$-hydroxy fatty acid with different chain lengths. The lipopeptides produced by various Bacillus sp., are further divided into different classes such as iturins (Delcambe et al. 1977), surfactins (Arima et al. 1968), fengycins (Vanittanakom et al. 1986), kurstakins (Hathout et al. 2000), bacillomycins (Roongsawang et al. 2002) and mycosubtilin (Duitman et al. 1999). Among these, iturins are the most widely reported class of lipopeptides produced by multiple strains of Bacillus subtilis (Duitman et al. 1999; Isogai et al. 1982; Peypoux et al. 1986), B. licheniformis (Kakinuma et al. 1969; Yakimov et al. 1999; Jenny et al. 1991; Lin et al. 1994) and B. cereus 
(Nishikiori et al. 1986). The lipopeptides like surfactin or iturin are synthesized by multifunctional enzymes encoded by large gene clusters (Kleinkauf and von Döhren 1995; Marahiel et al. 1997) and exhibit large diversity. Despite the fact that multiple bacteriocins and/or lipopeptide analogues are produced by a single strain, only few antimicrobial peptides are reported in the literature. Considering the enormous diversity of Bacillus species in the soil ecosystem it is very important to isolate and preserve the strains producing these antimicrobial peptides followed by detailed characterization. As a part of screening for biotechnologically potential soil microflora, we have earlier described a novel bacteriocin produced by a Brevibacillus laterosporus strain GI-9 (Singh et al. 2012). In present study we report another antimicrobial peptide and a cyclic lipopeptide produced by a halotolerant isolate of Bacillus subtilis strain SK.DU.4 isolated from a rhizosphere soil sample.

\section{Material and methods}

\section{Isolation of bacteria and identification}

The bacterial strain SK.DU.4 was isolated from a farmland soil sample. The sample was serially diluted and plated on different media to screen the bacteria producing antimicrobial substances. Selected colonies were streaked on to nutrient agar (NA) medium with the following composition $(\mathrm{g} / \mathrm{l})$ : peptic digest of animal tissue, 5.0; beef extract, 1.5; yeast extract, 1.5; sodium chloride, 5.0; agar 15.0 and the $\mathrm{pH}$ adjusted to 7.2. The isolates were checked for purity and preserved at $-70^{\circ} \mathrm{C}$ for further studies. The indicator strains used in this study were obtained from Microbial Type Culture Collection and Genebank (MTCC), Chandigarh, India and grown on tryptone soya agar (TSA) medium with the following composition (g/l): pancreatic digest of casein, 15.0; papaic digest of soybean meal, 5.0; sodium chloride, 5.0; agar 15.0 and the $\mathrm{pH}$ adjusted to 7.2. Strain SK.DU.4 was tested for various phenotypic properties including morphology, physiology and biochemical characteristics, according to the standard procedures. To confirm the identification of strain SK.DU.4, the 16S rRNA gene was amplified by PCR using universal primers and the amplified PCR product was sequenced as described earlier (Suresh et al. 2006). The 16S rRNA gene sequences of closely related strains were retrieved from EzTaxon server and aligned using CLUSTAL_W program of MEGA version 5.0 (Tamura et al. 2011). The alignment was corrected manually using BioEdit sequence alignment editor (Hall, 1999). Upon calculating the pair-wise evolutionary distances (Kimura, 1980), a neighbour-joining phylogenetic tree was constructed using the MEGA version 5.0.The strain was deposited at Microbial Type Culture Collection and Genebank, (MTCC 11460) and the 16S rRNA gene sequence was submitted to EMBL (HF544505) database.

\section{Determination of bacteriocin activity}

The bacteriocin activity was determined by well diffusion assay. The strain was grown for $24 \mathrm{~h}$ in $200 \mathrm{ml}$ nutrient broth (NB, Himedia) using $500 \mathrm{ml}$ flask and subsequently cells were removed by centrifugation $(8000 \mathrm{rpm}$ for $20 \mathrm{~min}, 4^{\circ} \mathrm{C}$ ). The supernatant obtained was filtered by using $0.22 \mu \mathrm{m}$ filter (Millipore), diluted by two fold and used to test the activity as mentioned earlier (Singh et al. 2012). The antimicrobial peptide production was also tested by growing the strain in minimal medium. To examine the antimicrobial activity, S. aureus cells were processed for scanning electron micrograph (SEM) as described by earlier (Singh et al. 2012). Growth curve was prepared to examine the bacteriocin production along with the growth of strain SK.DU4.

\section{Production and purification of bacteriocin}

To test the effect of different carbon and nitrogen sources like glucose, lactose, yeast extract, peptone and beef extract on production of antimicrobial peptides, $0.5 \%$ of each of them added to minimal medium with following composition (g/l): $\mathrm{Na}_{2} \mathrm{HPO}_{4} .2 \mathrm{H}_{2} \mathrm{O}, 7.9 ; \mathrm{KH}_{2} \mathrm{PO}_{4}, 3.0 ; \mathrm{NaCl}, 0.5$; $\mathrm{NH}_{4} \mathrm{Cl}, 1.0 ; \mathrm{pH}$ 7.2. The antimicrobial peptides production was measured as zone of inhibition against indicator strains. For the characterization of peptides, culture was grown in $1000 \mathrm{ml}$ of NB using 2 l flasks to obtain large quantity of antimicrobial peptides. One percent $(\mathrm{v} / \mathrm{v})$ of overnight grown culture of SK.DU.4 was inoculated to 11 of NB medium and grown for $24 \mathrm{~h}$ on a rotary shaker at $30^{\circ} \mathrm{C}$. Subsequently cells were separated by centrifugation $\left(8000 \mathrm{rpm}, 20 \mathrm{~min}\right.$ at $4^{\circ} \mathrm{C}$ ). The supernatant was mixed with $2 \%(\mathrm{w} / \mathrm{v})$ of Diaion HP-20 (Supelco, SigmaAldrich, USA) resin and the antimicrobial peptide was eluted in methanol. Methanol was evaporated using a rota vapour (BUCHI Rota vapor R-200), the antimicrobial peptide was redissolved in Milli-Q water and further purification was achieved through reverse phase HPLC (1260 Infinity, Agilent Technologies, USA) using a semi-preparative C18 column (Pursuit 10C18 250×21.2 mm). Acetonitrile and $0.1 \%$ TFA were used as mobile phase. The purified bacteriocin was tested for antimicrobial activity and applied on Tricine-SDS-PAGE (16\%)/6 M urea.

\section{Mass spectrometry and peptide mass fingerprint analysis}

Matrix-assisted laser desorption ionization (MALDI) was used to primarily characterize the antimicrobial bacteriocin. The lyophilized peptide was re-suspended in methanol and $4 \mu \mathrm{l}$ of peptide solution was mixed with $4 \mu \mathrm{l}$ of matrix (CHCA, $10 \mathrm{mg} / \mathrm{ml}), 1.0 \mu \mathrm{l}$ of this mixture solution was spotted onto the MALDI 100 well stainless steel sample plate and allowed to air dry prior to the MALDI analysis (Mandal et al. 2009). To obtain MALDI mass spectra, a Voyager time-of-flight mass spectrometer (Applied Biosystem, USA), equipped with $337 \mathrm{~nm} \mathrm{~N}_{2}$ laser was used 
and operated in accelerating voltage $20 \mathrm{kV}$. The spectra were recorded in positive ion linear mode. Reproducibility of the spectrum was checked several times from separately spotted samples. In order to carry out peptide mass fingerprint (pmf) analysis of the purified bacteriocin solution, the sample was lyophilized and dissolved in $50 \mathrm{mM}$ ammonium bicarbonate ( $\mathrm{pH}$ 8.0) buffer. Protein was reduced with $0.1 \mathrm{M} \mathrm{DTT}$ at $56^{\circ} \mathrm{C}$ for $30 \mathrm{~min}$ and alkylated with $0.3 \mathrm{M}$ iodoacetamide at room temperature for $15 \mathrm{~min}$ in the dark as described by Dey et al. (2012). Subsequently, the sample was subjected to digestion with trypsin at $37^{\circ} \mathrm{C}$ for overnight. One microliter of the digested sample was spotted directly onto a MALDI target plate and $1 \mu \mathrm{l}$ of CHCA matrix solution was applied on the sample spot and allowed to air dry. Mass spectra of different peptide fragments were acquired in positive ion reflector mode with a mass range of 700-5000 Da after an average of 1000 laser shots. Data was uploaded into MASCOT (Matrix Science, London, UK) database to search the protein identity. During database search the following parameters were considered: database, NCBInr; maximum missed cleavages, 1 ; precursor tolerance, $0.2 \mathrm{Da}$; peptide charges, +1 ; mass, monoisotopic.

\section{In-gel activity assay for detection of bacteriocin activity}

Tricine-sodium dodecyl sulfate-polyacrylamide gel electrophoresis (Tricine-SDS-PAGE) was performed for antimicrobial peptide using $16 \%$ polyacrylamide gel. The purified and concentrated antimicrobial peptide was applied onto the gel in duplicate. After the electrophoresis, a part of the gel along with molecular weight markers was stained with Coomassie Brilliant Blue R-250 to visualize the protein bands. Whereas the unstained part of the gel was used for in situ detection of bacteriocin activity upon fixing it in a mixture of 2-propanol, acetic acid and $\mathrm{H}_{2} \mathrm{O}$ (25:10:65) for 15 min and washed with sterile $\mathrm{H}_{2} \mathrm{O}$ for 30 min repeatedly. It was placed in a sterile Petri dish, overlaid with $10 \mathrm{ml}$ of soft agar (0.8\%) containing test strain S. aureus (about $10^{6}$ cells $/ \mathrm{ml}$ ).

\section{Determination of minimum inhibitory concentration}

The MIC of antimicrobial peptide was evaluated for different strains by using a microtiter plate dilution assay. Test strains grown to logarithmic phase under optimal conditions (between 0.3-0.4 OD) and used for assay in triplicates as described earlier (Singh et al. 2012). The lowest concentration that inhibited growth of test strain and did not show any increase in absorption after $48 \mathrm{~h}$ incubation was considered as MIC.

\section{Effect of $\mathrm{pH}$, temperature and hydrolytic enzymes on bacteriocin activity}

The antimicrobial peptide was checked for tolerance to different temperature, $\mathrm{pH}$ and proteases activity. To determine the tolerance to temperature and $\mathrm{pH}$, the purified peptide was incubated at different temperatures such as $60^{\circ}, 80^{\circ}, 100^{\circ}$ and $121^{\circ} \mathrm{C}$ for $15 \mathrm{~min}$ and $\mathrm{pH}$ values between 2.0-12.0. Different proteolytic enzymes including pepsin, trypsin, chymotrypsin, proteinase $\mathrm{K}$ and pronase $\mathrm{E}$ were incubated with peptide for $6 \mathrm{~h}$ at $37^{\circ} \mathrm{C}$ and the activity was terminated by heating at $80^{\circ} \mathrm{C}$ before the peptide was used for assay.

\section{Extraction of lipopeptide}

Lipopeptide was isolated from bacterial culture in a combination of acid and solvent extraction procedure following Vater et al. (2002). In brief, cells were removed from the $24 \mathrm{~h}$ growing culture broth by centrifugation $(13,000 \times \mathrm{g})$ for $15 \mathrm{~min}$ at $4^{\circ} \mathrm{C}$. The supernatant was adjusted to $\mathrm{pH} 2.0$ by addition of concentrated $\mathrm{HCl}$ and allowed to precipitate at $4^{\circ} \mathrm{C}$ for $16 \mathrm{~h}$. Precipitate was collected after centrifugation $(13,000 \times \mathrm{g})$ for $20 \mathrm{~min}$ at $4^{\circ} \mathrm{C}$ and extracted with methanol by stirring for $2 \mathrm{~h}$. The lipopeptide containing methanol was collected after filtration and vacuum-dried.

\section{Purification of lipopeptide}

The extracted lipopeptide dissolved in methanol and fractionated by reverse phase- HPLC (Agilent 1100 series) with a ZORBAX $300-S B 18$ column $(4.6 \mathrm{~mm} \times 250 \mathrm{~mm}$, particle size $5 \mu \mathrm{m}$ ), at a flow rate of $1 \mathrm{ml} / \mathrm{min}$. The solvent system used was $0.1 \%$ aqueous TFA (A) and acetonitrile containing $0.1 \%$ TFA (B). The gradient of solvent B used to run the column was as follows: $0-60 \%$ for $0-45 \mathrm{~min}$, $60-80 \%$ for $45-55 \mathrm{~min}$ and $80-100 \%$ for $55-60 \mathrm{~min}$. The elution from the column was monitored at $215 \mathrm{~nm}$ in a diode array detector and all the peaks of HPLC chromatogram were collected using a fraction collector (GILSON, France) coupled with the system. Collected fractions were concentrated by speed vacuum and antimicrobial activity was screened. The major fraction showing antibacterial activity was re-chromatographed in the same column under similar conditions, but solvent B was used as $100 \%$ ACN with a gradient of $0-10 \%$ for 30 min. Peptide concentration was determined using the RP-HPLC conditions and calibrated with surfactin (Sigma-Aldrich).

\section{MALDI-TOF-MS and sequencing}

The molecular mass of the purified active lipopeptide fraction was analysed following the protocol described above. For MS/MS sequencing, the peptide was incubated with $10 \% \mathrm{NaOH}$ in methanol at room temperature for $16 \mathrm{~h}$ to cleave the lactone ring. The cleaved peptide was lyophilized, again extracted with methanol and allowed for mass spectrometry analysis. The spectra were recorded in the post-source decay (PSD) ion mode as an average of 100 laser shots with a grid voltage of $75 \%$. The reflector voltage was reduced in $25 \%$ steps and 
guide wire was reduced $0.02-0.01 \%$ with an extraction delay time of $100 \mathrm{~ns}$.

\section{Fatty acid analysis by GC-MS}

Acid hydrolysis of lipopeptide was performed by incubating the peptide $(5 \mathrm{mg})$ with $0.5 \mathrm{ml}$ of $6 \mathrm{M} \mathrm{HCl}$ at $90^{\circ} \mathrm{C}$ for $18 \mathrm{~h}$ in sealed tubes. The fatty acids were extracted with ether and esterified with $0.95 \mathrm{ml}$ methanol and $0.05 \mathrm{ml}$ of $98 \% \mathrm{H}_{2} \mathrm{SO}_{4}$ at $65^{\circ} \mathrm{C}$ for $6 \mathrm{~h}$. Fatty acid methyl esters were obtained after extraction with n-hexane and analyzed by GC-MS with a Clarus 500 GC (PerkinElmer, USA). Helium was used as carrier gas at a flow rate of $1.0 \mathrm{ml} / \mathrm{min}$. The column temperature was maintained at $120^{\circ} \mathrm{C}$ for $3 \mathrm{~min}$ and thereafter gradually increased $\left(8^{\circ} \mathrm{C} / \mathrm{min}\right)$ to $260^{\circ} \mathrm{C}$.

\section{Results}

\section{Characterization of bacterial strain}

A strain, designated SK.DU.4, has been shown to exhibit antibacterial activity as revealed by the clearing zone assay while screening. To this effect, we sought to investigate the molecular basis of its antimicrobial activity. Initial efforts to identify the strain by phenotypic characteristics revealed that the strain SK.DU.4 was a Gram-positive, rod shaped, endo-spore forming bacteria with positive reaction for catalase activity and negative for oxidase activity. It produces amylase and proteases as revealed by starch and skim milk hydrolyses. It grew between $10^{\circ}$ to $50^{\circ} \mathrm{C}$ temperature. Positive for methyl red and nitrate reduction but negative for indole test and urea hydrolysis. All these phenotypic properties are in agreement with members of the genus Bacillus, known to produce diverse antimicrobial peptides. In addition to the phenotypic identification, the BLAST analysis of $16 \mathrm{~S}$ rRNA gene sequence revealed significant identity (99.8\%) with B. subtilis subsp. inaquosorum, a strain shown to produce surfactin-like lipopeptide. Further, the neighbour joining phylogenetic tree constructed with $16 \mathrm{~S}$ rRNA gene sequences of other members of the genus Bacillus confirmed that strain SK.DU.4 belongs to genus Bacillus as it formed a distinct cluster along with other subspecies of B. subtilis (Figure 1). Although strain SK.DU.4 showed highest similarity with $B$. subtilis subsp. inaquosorum, it formed a clade with B. subtilis subsp. spizizenii, with low bootstrap value. Therefore, strain SK.DU.4 was assigned as another strain of $B$. subtilis. The growth curve analysis along with studies on antimicrobial production indicates that the strain SK.DU.4 also produces a peptide like antimicrobial substance during stationary growth phase (Figure 2). Notably, there is a significant increase in antimicrobial peptide production during 14 to $18 \mathrm{~h}$ and the

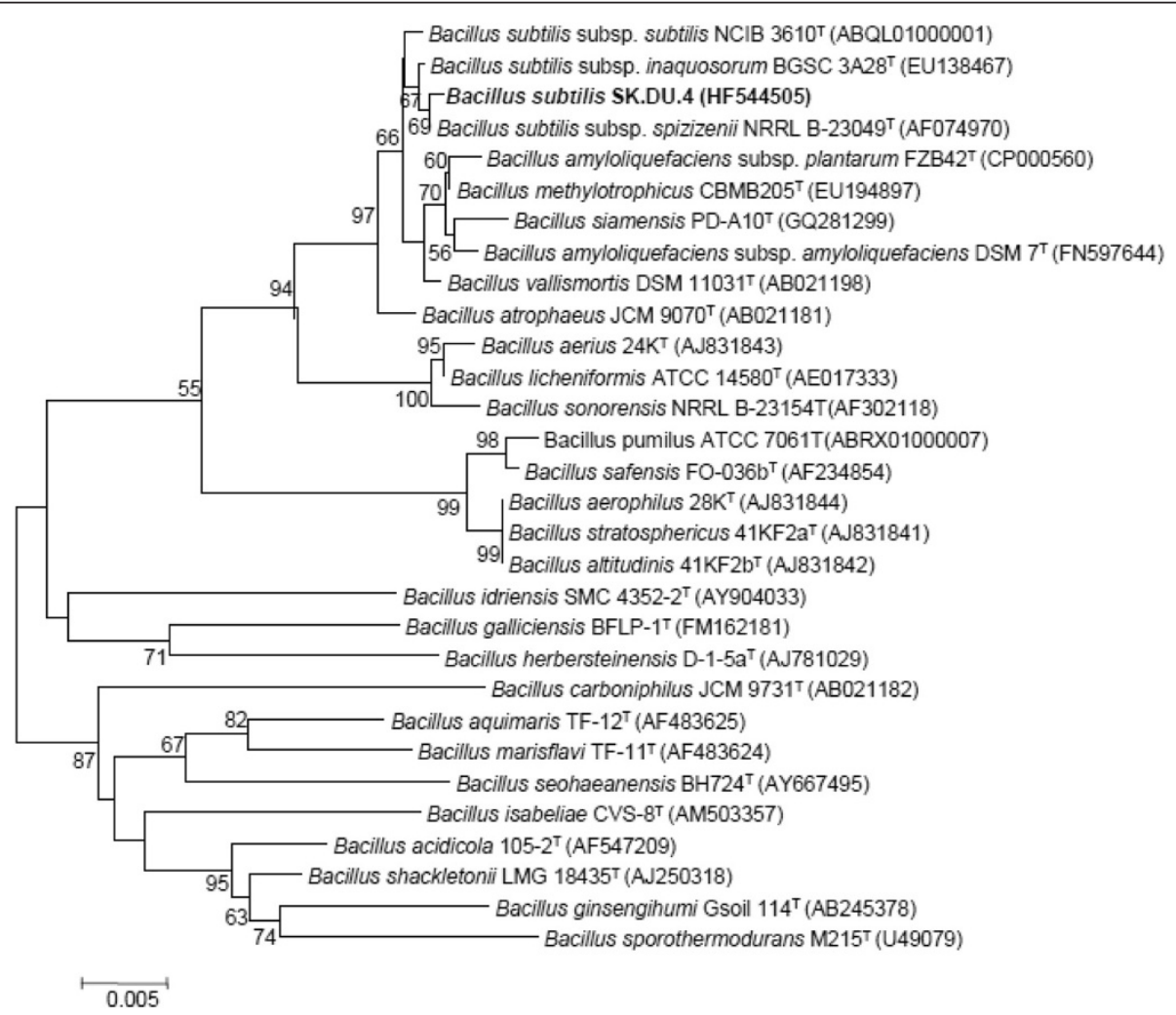

Figure 1 Neighbour-joining phylogenetic tree based on 16S rRNA gene sequences, showing the phylogenetic relationship between strain SK.DU.4 and other members of the genus Bacillus. Bootstrap values greater than $50 \%$ are given at the nodes. 


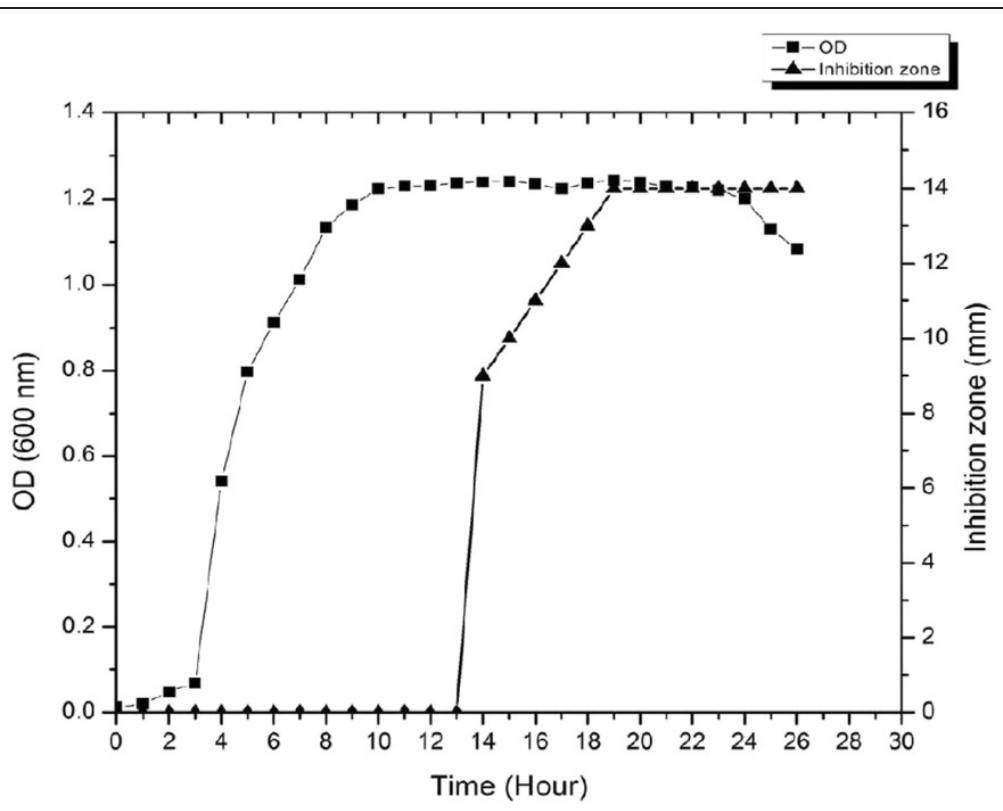

Figure 2 Growth phase-dependent bacteriocin production by Bacillus subtilis strain SK.DU.4. While filled squares represent bacterial growth as measured by absorbance at $600 \mathrm{~nm}$, filled triangles indicate corresponding bacteriocin activity as determined by inhibition zone assay.

antimicrobial activity remained constant thereafter as measured by inhibition zone.

\section{Production and purification of antimicrobial peptide}

Although the antimicrobial peptides were produced in NB for large scale preparation, the influence of different carbon and nitrogen sources on peptides production was tested using minimal medium. As revealed by inhibition zone, increased production of antimicrobial peptides was observed with addition of beef extract $(15 \mathrm{~mm})$ followed by the combination of glucose and yeast extract $(14 \mathrm{~mm})$, and peptone $(13 \mathrm{~mm})$ after $24 \mathrm{~h}$. The optimum $\mathrm{pH}$ for the production of antimicrobial peptides was 7.2 and there was no significant change in $\mathrm{pH}$ was observed during the production of antimicrobial peptides. The bacteriocin-like peptide was extracted from CFB by hydrophobic interaction chromatography using Diaion HP-20 beads and purified by a combination of chromatography techniques as described previously (Singh et al. 2012). Subsequently, the purified peptide was tested for antimicrobial activity against an array of Gram-positive and Gram-negative bacteria, yeasts and fungi strains using well diffusion assays. Interestingly, the antimicrobial peptide shows antibacterial activity against Grampositive bacteria only, without a detectable effect against yeast (Table 1). The influence of medium composition for antimicrobial activity of the peptide was ruled out as comparable results of antimicrobial activity of strain SK. DU.4 obtained while grown on minimal medium.

\section{Characterization of bacteriocin-like peptide}

The peptide obtained by affinity chromatography was purified by RP-HPLC and used to determine molecular mass by MALDI-TOF analysis. Additionally, the antimicrobial peptide obtained during the lipopeptide extraction (fraction 4; Figure 3A) yielded single band in SDS-PAGE analysis (Figure 3B) and showed antimicrobial activity against S. aureus in in-gel assay (Figure $3 C$ ). Therefore, it was also included for mass determination. Both peptides showed molecular mass of 5323.9 Da $(+1)$ and 2621.4 Da $(+2)$ of antimicrobial peptide (Figure $4 \mathrm{~A}$ ), suggesting that it is a bacteriocin-like peptide. Further, the bacteriocin-like peptide was subjected to tryptic digestion. After tryptic digestion, the pmf analysis was performed by Matrix Science Mascot UK software, and significant $(\mathrm{P}<0.05)$ result was obtained. The analysis revealed that five peptide sequences have similarity with the stretches of secreted lipoprotein of Methylomicrobium album BG8 (Protein View: gi| 381152247 ) and displayed $70 \%$ coverage with a significant homology (Figure 5).

\section{Inhibition spectrum and sensitivity of the bacteriocin-like peptide}

The antimicrobial peptide displayed a narrow spectrum activity and was active against Gram-positive bacteria such as L. monocytogenes (MTCC839), S. aureus (MTCC1430), S. mutans (MTCC497) and M. luteus (MTCC106). The scanning electron microscopy (SEM) of S. aureus (MTCC1430) treated with $6.0 \mu \mathrm{M}$ concentration of bacteriocin-like 
Table 1 Inhibition spectrum of bacteriocin-like peptide and lipopeptide produced by strain SK.DU.4

\begin{tabular}{|c|c|c|c|c|}
\hline \multirow{2}{*}{$\begin{array}{l}\text { Indicator } \\
\text { species }\end{array}$} & \multirow[t]{2}{*}{ Strain } & \multicolumn{3}{|c|}{ Inhibition activity } \\
\hline & & $\begin{array}{l}\text { Bacteriocin- } \\
\text { like peptide }\end{array}$ & Lipopeptide & $\begin{array}{c}\text { Polymyxin } \\
\text { B (300 U) }\end{array}$ \\
\hline S. aureus & MTCC1430 & + & + & + \\
\hline B. subtilis & MTCC121 & - & + & + \\
\hline B. subtilis & MTCC441 & - & - & + \\
\hline B. subtilis & MTCC619 & - & - & + \\
\hline B. subtilis & MTCC736 & - & + & + \\
\hline B. subtilis & MTCC1427 & - & + & + \\
\hline B. subtilis & MTCC2423 & - & + & + \\
\hline B. subtilis & MTCC9878 & - & + & + \\
\hline L. monocytogenes & MTCC839 & + & + & + \\
\hline S. mutans & MTCC497 & + & - & + \\
\hline M. luteus & MTCC106 & + & + & + \\
\hline E. coli & MTCC1610 & - & - & + \\
\hline V. cholerae & MTCC3904 & - & - & + \\
\hline P. aeruginosa & MTCC1934 & - & - & + \\
\hline S. marcescens & MTCC97 & - & - & + \\
\hline C. freundii & MTCC1658 & - & - & + \\
\hline A. faecalis & MTCC3104 & - & - & + \\
\hline A. baumannii & MTCC1425 & - & - & + \\
\hline P. vulgaris & MTCC1771 & - & - & + \\
\hline C. albicans & MTCC1637 & - & - & - \\
\hline Asperigillus terreus & Lab isolate & - & + & - \\
\hline
\end{tabular}

peptide showed accumulation of cell debris in the medium (Figure 4C). The MIC analysis of purified peptide revealed $S$. aureus and L. monocytogenes are more sensitive strains and are inhibited at lower concentrations of the peptide compared to other test strains (Figure 6). No activity could be detected when tested for other Gram-negative bacteria included in the assay. The results of heat stability assay of the antimicrobial peptide shows that the antimicrobial activity is retained as high as $80^{\circ} \mathrm{C}$ for $15 \mathrm{~min}$. Clearly, there was sharp decrease in activity with increase in temperature up to $100^{\circ} \mathrm{C}$ and no activity observed when the peptide was autoclaved $\left(121^{\circ} \mathrm{C}\right.$ for $\left.15 \mathrm{~min}\right)$. The peptide did not show a change in its activity profile between $\mathrm{pH} 3.0$ - 9.0, however, the activity sharply reduced to almost undetectable level above $\mathrm{pH}$ 9.0. No activity was observed at $\mathrm{pH}$ 2.0 and 10.0. Significant decrease in antimicrobial activity was observed when the peptide was incubated with pepsin, trypsin, chymotrypsin, pronase $\mathrm{E}$ and proteinase $\mathrm{K}$ for $6 \mathrm{~h}$. Complete loss of antimicrobial activity was observed with overnight incubation of the peptide with above proteases. Interestingly, the antimicrobial peptide showed increase in activity when combined with lipopeptide produced by strain SK.DU.4 (Figure 4D).

\section{Lipopeptide purification and MS/MS sequencing}

In contrast to bacteriocin-like peptide, the lipopeptide from liquid culture-grown supernatant was extracted as methanolic extract and separated using RP-HPLC. Four fractions were observed during HPLC separation (Figure 3A). After lyophilization, all fractions were tested for antimicrobial activity and found that fractions 2 and 4 exhibiting antimicrobial activity. Fraction 4 was identified as bacteriocin-like peptide as described above and fraction 2 showed a low molecular mass of $1056 \mathrm{Da}$ (Figure 4B). The primary structure elucidation of the fraction 2 peptide was made using a combination of mass spectrometry techniques. The peaks obtained for different fragments at $\mathrm{m} / \mathrm{z} 836,721,558,444,316,219$, 105 and 18 in MS/MS analysis revealed the lipopeptide sequence as Asp-Tyr-Asn-Gln-Pro-Asn-Ser (Figure 7). The C-terminal amino acid in peptide was linked to
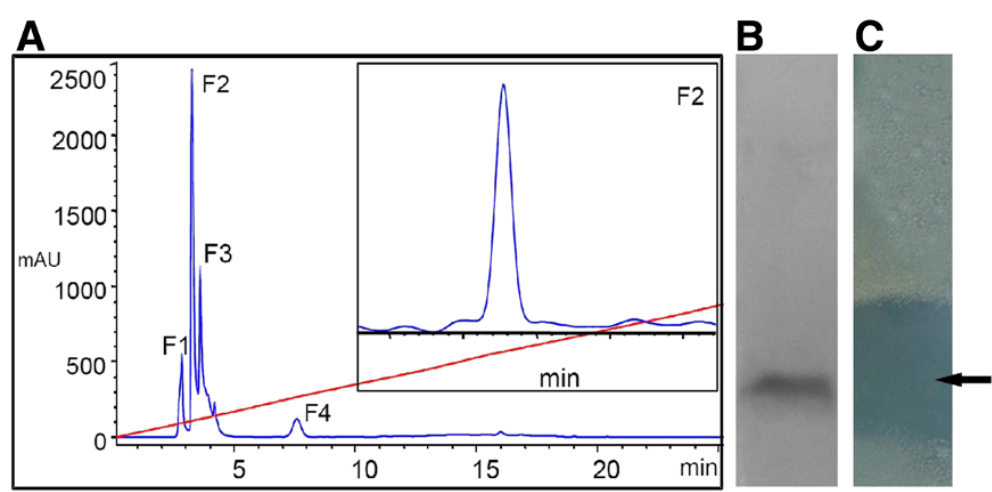

Figure 3 Separation of the antimicrobial lipopeptide from acidic methanol extract by using reversed-phase HPLC. (A) Chromatogram profile of acidic methanol extract showed four peaks (F1-F4) and among these fractions F2 (lipopeptide) and F4 (bacteriocin-like peptide) showed antimicrobial activity. Diagonal red line indicates the gradient of solvent B; inset picture shows the re-chromatogram profile of lipopeptide fraction (F2). (B) Tricine-SDS-PAGE of the purified bacteriocin-like peptide. (C) Direct overlay of the SDS-PAGE gel demonstrating a clear inhibition zone against test strain $S$. aureus (indicated with arrow). 

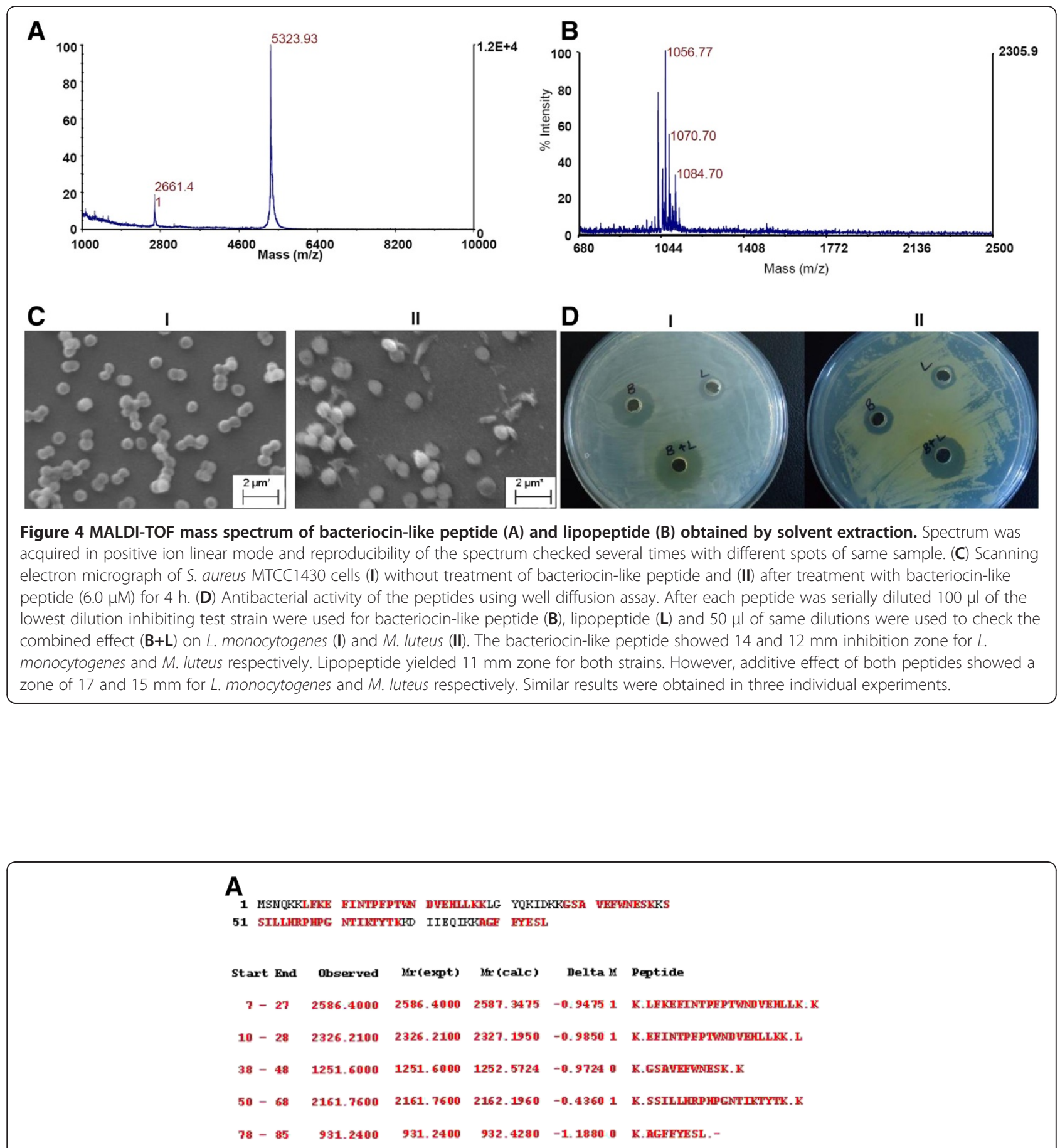

B

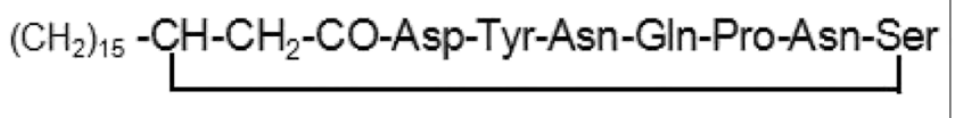

Figure 5 (A) Peptide mass fingerprinting (pmf) analysis of bacteriocin-like antimicrobial peptide (5324 Da). The pmf followed by MASCOT (Matrix Science, London, UK) search shows the matched amino acid residues (in red bold) of the peptide fragments with the putative periplasmic or secreted lipoprotein [Methylomicrobium album BG8] following NCBI blast search. (B) Amino acid sequence of the lipopeptide obtained by solvent extraction. 


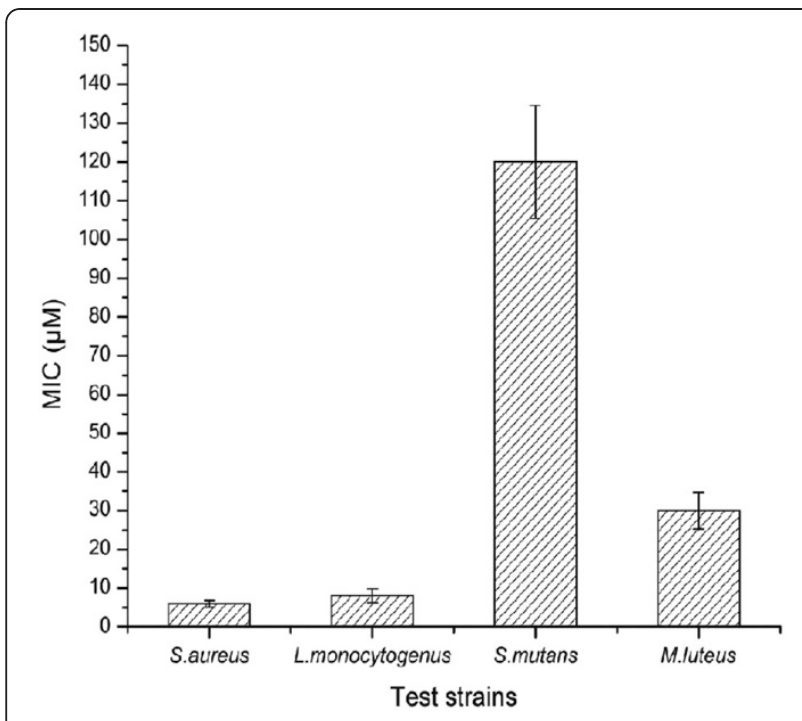

Figure 6 Determination of MIC for purified bacteriocin-like antimicrobial peptide towards different Gram-positive indicator strains. The micro-titre plate assay performed in triplicates revealed that L. monocytogenes and S. aureus are highly sensitive.

hydroxyl group of a $\beta$-hydroxy-fatty acid through lactone ring, a characteristic feature observed for cyclic lipopeptides. Based on the amino acid composition, fraction 2 lipopeptide was identified as member of the iturin family biosurfactants with a mass value of $\mathrm{m} / \mathrm{z} 1056 \mathrm{Da}$.

\section{Discussion}

Antimicrobial peptides are produced as defensin molecules by many Gram-positive bacteria including Bacillus in complex environments. Habitats like rhizosphere provide competitive environment resulting in multiple strains producing antimicrobial peptides that exhibit selective spectrum of inhibition. In addition to antimicrobial peptides, many strains of bacteria are reported to produce a variety of antimicrobial biosurfactants like lipopeptide antibiotics, classified as iturins or surfactins (Chen and Hoover 2003). Screening and characterization of these novel antimicrobial peptides has attracted attention of many researchers due to their potential applications in therapeutic and food industry. Moreover, combined production of antimicrobial peptide and bioactive lipopeptide by a single strain can import additional benefits to the strain(s) for commercial applications like food preservation. Likewise, few strains of Bacillus subtilis known to produce various antimicrobial peptides including lipopeptides with potential applications (Toure et al. 2004; Chen et al. 2008) and in few instances co-production of a variety of lipopeptides like surfactin/iturin or surfactin/mycosubtilin have been reported from Bacillus sp. (Huang et al. 1993; Duitman et al. 1999). However, co-production of bacteriocin-like antimicrobial peptide and a lipopeptide has never been reported for any strain of the genus Bacillus. In the present study, we report a novel strain SK.DU.4, identified during screening of soil bacteria for antimicrobial substances production, which produces both bacteriocin-like peptide and lipopeptide. Although strain SK.DU.4 showed highest similarity with $B$. subtilis subsp. inaquosorum (99.8\% similarity) during blast search of $16 \mathrm{~S}$ rRNA gene sequence, it differed in phenotypic properties such as presence of ellipsoidal endospore and growth at $14 \% \mathrm{NaCl}$ concentration with the closest

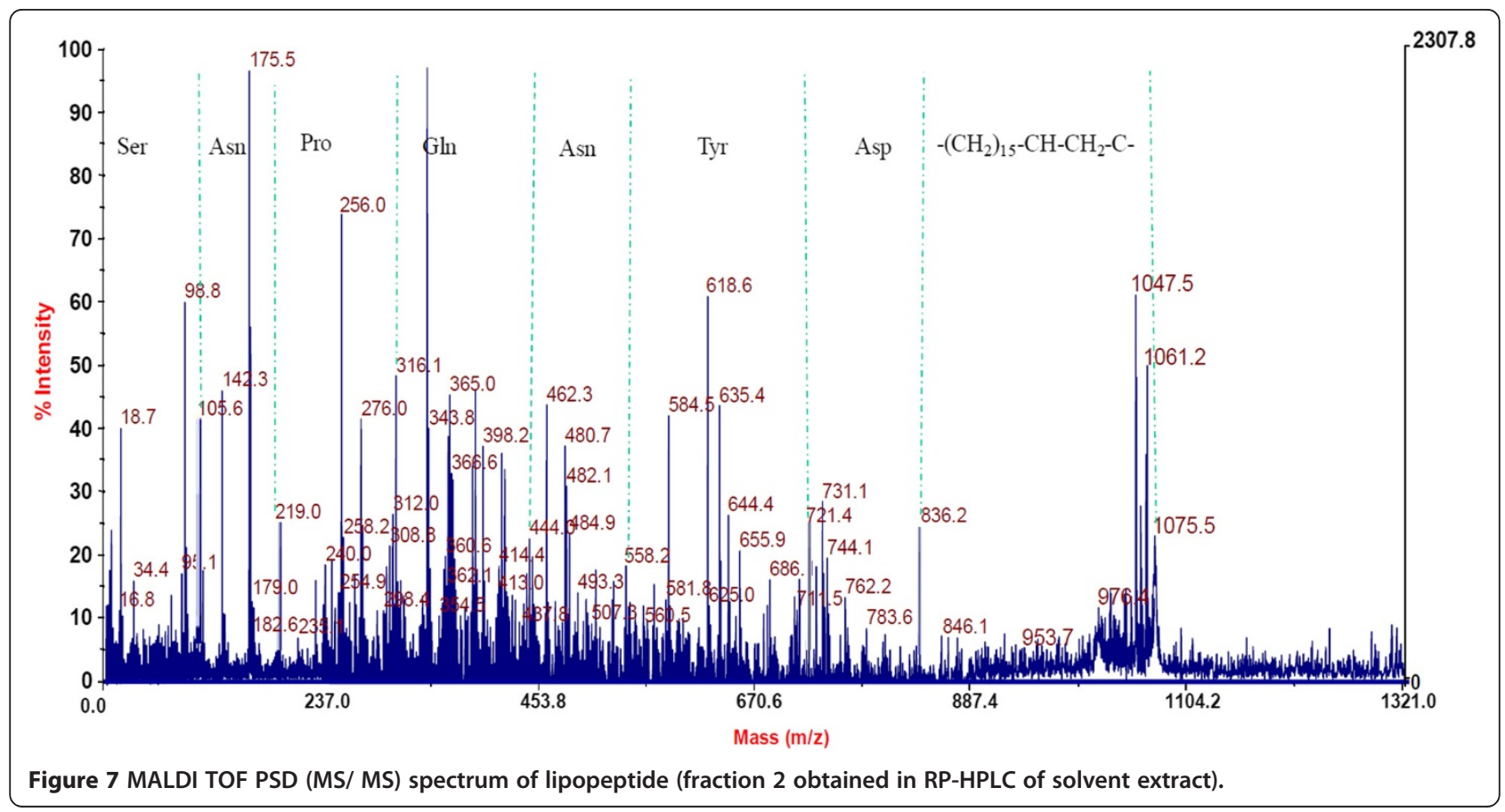


phylogenetic relative $B$. subtilis subsp. inaquosorum. In addition, the lipopeptide molecular mass of strain SK.DU.4 differed with surfactin-like lipopeptide $(1120.8 \mathrm{~m} / \mathrm{z})$ produced by $B$. subtilis subsp. inaquosorum (Rooney et al. 2009). Further characterization of the antimicrobial peptides produced by strain SK.DU.4 revealed that it produced a bacteriocin-like peptide and an iturin like lipopeptide. Although production of multiple peptides by a single strain imparts biotechnological potential to the producing microorganism, purification of the peptides involves additional complications. However, the purification of bacteriocin like antimicrobial peptide in this study was achieved by a combination of size exclusion, affinity and reversed phase chromatography techniques as described previously (Singh et al. 2012). In contrast, the lipopeptides which exist as homologues with marginal differences in their physicochemical properties (Wang et al. 2004) were solvent extracted from liquid culture-grown supernatant (Vater et al. 2002) and subsequently purified by reversed phase chromatography.

The pmf analysis of $5.3 \mathrm{kDa}$ antimicrobial peptide revealed high similarity with the lipoprotein of Methylomicrobium album, a secreted hydrolytic enzyme that are known to degrade the structural components of the cell wall and thereby exhibiting antimicrobial activity (Collmer and Keen 1986). Similarly, disintegration of the cell wall might be the cause of antimicrobial activity of the bacteriocin-like peptide as cell debris observed in the surroundings of the treated cells (Figure 4C II). Nevertheless, no lipid moiety was detected in TLC experiments carried out for the detection of total lipids of the antimicrobial peptide. However, characteristics like the lowmolecular-weight, narrow spectrum antimicrobial activity against Gram-positive bacteria, sensitivity to proteolytic enzymes and resistance to high temperature identified the peptide as a bacteriocin-like antimicrobial peptide belonging to class II nonmodified peptides (Klaenhammer 1993). Strains of the genus Bacillus produces a wide variety of bacteriocins that are encoded by a cluster of genes comprising structural, transportation, immunity, regulatory and other genes required for post-translational modifications (Le Marrec et al. 2000; Lee et al. 2009; Abriouel et al. 2011). Antimicrobial peptides produced by members of the genus Bacillus are classified under both bacteriocins with post-translational modifications and nonmodified antimicrobial peptides (Abriouel et al. 2011). However, peptide mass fingerprint analysis of the peptide in this study yielded different fragments (Figure 6) and the bioinformatic analysis of one of the largest peptide fragment sequence (KLFKEFINTPEPTWNDVEHLLKK) showed 34\% hydrophobicity. The motif -LFKEFI- at N-terminal site of the sequence is interesting where KE, the hydrophilic residues are surrounded by hydrophobic residues (LF and FI) are might be important for cell penetration and cell membrane interaction. Furthermore, the presence of a bioactive lipopeptide peak in RP-HPLC analysis of solvent extract (Figure 3A) revealed that the strain SK.DU.4 also produced an antimicrobial surfactant. Antimicrobial lipopetides are known to produce by various strains of $B$. subtilis and they includes iturin, bacillomycin, mycosubtilin and fengycin with molecular weight ranging between 1028-1084 Da and exhibit strong antimicrobial activity towards many pathogenic fungi (Vanittanakom et al. 1986; Duitman et al. 1999; Yu et al. 2002; Chen et al. 2008). These amphipathic lipopeptides are non-ribosomal peptides biosynthesized by large multi-enzymes called non-ribosomal peptide synthetases (NRPSs) with modularly arranged catalytic domains (Peypoux et al. 1999; Finking and Marahiel 2004). Therefore, to probe the composition and activity of the isolated lipopeptide, its primary structure was determined using a combination of chemical reactions and a variety of mass spectrometry techniques. Based on the presence of $\beta$ hydroxy fatty acid moiety, hepta peptide and its amino acid composition, the lipopeptide was identified as a member of the iturin family. However, it exhibited stronger antibacterial activity than antifungal activity when compared with other members of the iturin family. Additionally, strain SK. DU.4 contained aspartic acid (D) compared to asparagine $(\mathrm{N})$ in iturins and mycosubtilin in their N-terminal consensus sequence Asx-Tyr-Asn. Though, the sequence of AspTyr-Asn was observed at N-terminal for bacillomycin (Peypoux et al. 1986), it differed with lipopeptide of strain SK.DU.4 in the composition of other amino acids. The lipopeptide was not tested for any surfactant activity as there are no hydrophobic amino acids observed in the sequence. Lipopeptides easily bind to the bacterial surface bilayer and alter the local lipid organizational linking on negatively charged fatty acids resulting in restructuring of the lipid bilayer and prevent cellular processes (Horn et al. 2012). The fatty acid moiety is also found to play an important role in antimicrobial activity of lipopeptides (Boeck et al. 1989) and members of the iturin family lipopetides including iturin A, bacillomycin D, bacillomycin F, bacillomycin $\mathrm{L}$ and bacillomycin Lc, contained a $\beta$-hydroxy fatty acid with 14 carbon chain length and inhibited different species of fungi but exhibited limited activity against bacteria (Vanittanakom et al. 1986; Zeriouh et al. 2011). In comparison, the lipopeptide in this study contained a $\beta$ hydroxy fatty acid of 15 carbon chain length and showed stronger antibacterial activity. Although the lipopeptide inhibited growth of B. subtilis (MTCC121), it did not inhibit the growth of other $B$. subtilis strains including producing strain SK.DU.4. Lipopeptide also inhibited the growth of strains like S. mutans in combination with bacteriocin-like peptide. Thus, the additive effect of both peptides exhibited increase in antimicrobial activity against Gram-positive bacteria.

In conclusion, strain designated as SK.DU.4, identified as Bacillus subitlis produced two novel antimicrobial 
peptides that are active against a variety of Gram-positive bacteria. The co-production of these antimicrobial peptides by strain SK.DU.4 increased its applications as a biocontrol agent or in food preservation due to its high antimicrobial activity against $S$. aureus and L. monocytogenes, which are frequently connected to food spoilage.

\section{Competing interest}

The author(s) declare that they have no competing interests.

\section{Acknowledgement}

Financial assistance from Department of Biotechnology (DBT) and Council of Scientific and Industrial Research (CSIR), Govt of India is acknowledged. We thank Mr. Deepak Bhatt for his help in 165 rRNA gene sequencing. We are also thankful to Mr. Anil Theophilus for his help in electron microscopy, Ms. Sukhpreet Kaur and Ms. Alpa Pajiala for their technical assistance. This is IMTECH communication no. 072

\section{Author details}

${ }^{1}$ MTCC and Gene Bank, CSIR-Institute of Microbial Technology, Sector 39A, Chandigarh 160036, India. ${ }^{2}$ Central Research Facility, Indian Institute of Technology Kharagpur, Kharagpur, West Bengal 721302, India.

Received: 29 December 2012 Accepted: 2 January 2013 Published: 5 January 2013

\section{References}

Abriouel H, Franz CM, Ben Omar N, Galvez A (2011) Diversity and applications of Bacillus bacteriocins. FEMS Microbiol Rev 35:201-232

Arima K, Kakinuma A, Tamura G (1968) Surfactin, a crystalline peptide lipid surfactant produced by Bacillus subtilis: isolation, characterization and its inhibition of fibrin clot formation. Biochem Biophys Res Commun 31:488-494

Boeck LD, Fukuda DS, Abbott BJ, Debono M (1989) Deacylation of echinocandin B by Actinoplanes utahensis. J Antibiot (Tokyo) 42:382-388

Chen H, Hoover DG (2003) Bacteriocins and their food applications. Compr Rev Food Sci Food Saf 2:82-100

Chen H, Wang L, Su CX, Gong GH, Wang P, Yu ZL (2008) Isolation and characterization of lipopeptide antibiotics produced by Bacillus subtilis. Lett Appl Microbiol 47:180-186

Collmer A, Keen NT (1986) The role of pectic enzymes in plant pathogenesis. Ann Rev Phytopathol 24:383-409

Cotter PD, Hill C, Ross P (2005) Bacteriocins: developing innate immunity for food. Nat Rev Microbiol 3:777-788

Deegan HL, Cotter PD, Hill C, Ross P (2006) Bacteriocins: biological tools for biopreservation and shelf-life extension. Int Dairy J 16:1058-1071

Delcambe L, Peypoux F, Besson F, Guinand M, Michel G (1977) Structure of iturinlike substances. Biochem Sco Trans 5:1122-1124

Dey P, Kamdar MR, Mandal SM, Maiti MK (2012) Identification of an extracellular antifungal protein from the endophytic fungus Colletotrichum sp. DM06. Protein Pept Lett, In press

Duitman HE, Hamoen LW, Rembold M, Venema G, Seitz H, Saenger W, Bernhard F, Reinhard R, Schmidt M, Ullrich C, Stein T, Leenders F, Vater J (1999) The mycosubtilin synthetase of Bacillus subtilis ATCC6633: a multifunctional hybrid between a peptide synthetase, an amino transferase and a fatty acid synthase. PNAS 96:13294-13299

Finking R, Marahiel MA (2004) Biosynthesis of non-ribosomal peptides. Annu Rev Microbiol 58:453-488

Hall TA (1999) BioEdit: a user-friendly biological sequence alignment editor and analysis program for Windows 95/98/NT. Nucleic Acids Symp Ser 41:95-98

Hathout Y, Ho Y-P, Ryzhov V, Demirev P, Fenselau C (2000) Kurstakins: a new class of lipopeptides isolated from Bacillus thuringiensis. J Nat Prod 63:1492-1496

Holzapfel WH, Geisen R, Schillinger U (1995) Biological preservation of foods with reference to protective cultures, bacteriocins and food-grade enzymes. Int J Food Microbiol 24:343-362

Horn JN, Sengillo JD, Lin D, Romo TD, Grossfield A (2012) Characterization of a potent antimicrobial lipopeptide via coarse-grained molecular dynamics. Biochim Biophys Acta 1818:212-218
Huang CC, Ano T, Shoda M (1993) Nucleotide sequence and characteristic of the gene, Ipa-14, responsible of biosynthesis of the lipopeptide antibiotics iturin A and surfactin from Bacillus subtilis RB14. J Ferment Bioeng 76:445-450

Isogai I, Takayama S, Murakoshi S, Suzuki A (1982) Structure of $\beta$-amino acids in antibiotic iturin A. Tetrahedron Lett 23:3065-3068

Jenny K, Kappeli O, Fiechter A (1991) Biosurfactants from Bacillus licheniformis structural analysis and characterization. Appl Microbiol Biotechnol 36:1669-1671

Kakinuma A, Ouchida A, Shima T, Sugino H, Isono M, Tamura G, Arima K (1969) Confirmation of the structure of surfactin by mass spectrometry. Agric Biol Chem 33:1669-1671

Kimura M (1980) A simple method for estimating evolutionary rates of base substitutions through comparative studies of nucleotide sequences. J Mol Evol 16:111-120

Klaenhammer T (1993) Genetics of bacteriocins produced by lactic acid bacteria. FEMS Microbiol Rev 12:39-86

Kleinkauf H, von Döhren H (1995) The nonribosomal peptide biosynthetic system-on the origins of structural diversity of peptides, cyclopeptides and related compounds. Anton Van Lee 67:229-242

Le Marrec C, Hyronimus B, Bressollier P, Vemeuil B, Urdaci MC (2000) Biochemical and genetic characterization of coagulin, a new antilisterial bacteriocin in the pediocin family of bacteriocins, produced by Bacillus coagulans 14. Appl Environ Microbiol 66:5213-5220

Lee H, Churey JJ, Worobo RW (2009) Biosynthesis and transcriptional analysis of thurincin $\mathrm{H}$, a tandem repeated bacteriocin genetic locus, produced by Bacillus thuringiensis SF361. FEMS Microbiol Lett 229:205-213

Lin SC, Minton MA, Sharma MM, Georgiou G (1994) Structural and immunological characterization of a biosurfactant produced by Bacillus licheniformis JF-2. Appl Environ Microbiol 60:31-38

Mandal SM, Dey S, Mandal M, Sarkar S, Maria-Neto S, Franco OL (2009) Identification and structural insights of three novel antimicrobial peptides isolated from green coconut water. Peptides 30:633-637

Marahiel MA, Stachelhaus T, Mootz HD (1997) Modular peptide synthetases involved in nonribosomal peptide synthesis. Chem Rev 97:2651-2673

Mukherjee S, Das P, Sen R (2006) Towards commercial production of microbial surfactants. Trends Biotechnol 24:509-515

Nishikiori T, Naganawa H, Muraoka Y, Aoyagi T, Umezawa H (1986) Plipasatins: new inhibitors of phospholipase A2 produced by Bacillus cereus BMG302fF67.III. Structural elucidation of plipastatins. J Antibiot 35:755-761

Peypoux F, Pommier MT, Das BC, Besson F, Delcambe L, Michel G (1986) Structures of bacillomycin $D$ and bacillomycin $L$ peptidolipid antibiotics from Bacillus subtilis. J Antibiot 37:1600-1604

Peypoux F, Bonmatin JM, Wallach J (1999) Recent trends in the biochemistry of surfactin. Appl Microbiol Biotechnol 51:553-563

Rodrigues L, Banat IM, Teixeira J, Oliveira R (2006) Biosurfactants: potential applications in medicine. J Antimicrob Chemother 57:609-618

Rooney PA, Price PJN, Ehrhardt C, Swezey LJ, Bannan DJ (2009) Phylogeny and molecular taxonomy of the Bacillus subtilis species complex and description of Bacillus subtilis subsp. inaquosorum subsp. nov. Int J Syst Evol Microbiol 59:2429-2436

Roongsawang N, Thaniyavarn J, Thaniyavarn S, Kameyama T, Haruki M, Imanaka T, Morikawa M, Kanaya S (2002) Isolation and characterization of halotolerant Bacillus subtilis BBK-1 which produces three kinds of lipopeptides: bacillomycin L, plipastatin and surfactin. Extremophiles 6:499-506

Singh PK, Chittpurna A, Sharma V, Patil PB, Suresh K (2012) Identification, purification and characterization of laterosporulin, a novel bacteriocin produced by Brevibacillus sp. Strain GI-9. PLoS One 7(3):e31498

Suresh K, Mayilraj S, Chakrabarti T (2006) Effluviibacter roseus gen. nov. sp. nov., isolated from muddy water, belonging to the family "Flexibacteraceae". Int J Syst Evol Microbiol 56:1703-1707

Tamura K, Peterson D, Peterson N, Stecher G, Nei M, Kumar S (2011) MEGA5: molecular evolutionary genetics analysis using maximum likelihood, evolutionary distance and maximum parsimony methods. Mol Biol Evol 28:2731-2739

Toure $Y$, Ongena M, Jacques P, Guiro A, Thonart P (2004) Role of lipopeptides produced by Bacillus subtilis GA1 in the reduction of grey mould disease caused by Botrytis cinerea on apple. J Appl Microbiol 96:1151-1160

Vanittanakom N, Loeffler W, Koch U, Jung G (1986) Fengycin- a novel antifungal lipopeptide antibiotic produced by Bacillus subtilis F-29-3. J Antibiot 39:888-901 
Vater J, Kablitz B, Wilde C, Franke P, Mehta N, Cameotra SS (2002) Matrix-assisted laser desorbtion ionization-time of flight mass spectrometry of lipopeptide biosurfactants in whole cells and culture filtrates of Bacillus subtilis C-1 isolated from petroleum sludge. Appl Environ Microbiol 68:6210-6219

Wang J, Liu J, Wang X, Yao J, Yu Z (2004) Application of electrospray ionization mass spectrometry in rapid typing of fengycin homologues produced by Bacillus subtilis. Lett Appl Microbiol 39:98-102

Yakimov MM, Abraham W-R, Meyer H, Giuliana I, Golyshin PN (1999) Structural characterization of lichenysin A components by fast atom bombardment tandem mass spectrometry. Biochim Biophys Acta 1438:273-280

Yu GY, Sinclair JB, Hartman GL, Bertagnolli BL (2002) Production of iturin A by Bacillus amyloliquefaciens suppressing Rhizoctonia solani. Soil Biol Biochem 34:955-963

Zeriouh H, Romero D, Garcia-Gutierrez L, Cazorla FM, de Vicente A, Perez-Garcia A (2011) The iturin-like lipopeptides are essential components in the biological control arsenal of Bacillus subtilis against bacterial diseases of cucurbits. Mol Plant Microbe Interact 24:1540-1552

doi:10.1186/2191-0855-3-2

Cite this article as: Baindara et al.: Characterization of two antimicrobial peptides produced by a halotolerant Bacillus subtilis strain SK.DU.4

isolated from a rhizosphere soil sample. AMB Express 2013 3:2.

\section{Submit your manuscript to a SpringerOpen ${ }^{\circ}$} journal and benefit from:

- Convenient online submission

- Rigorous peer review

- Immediate publication on acceptance

- Open access: articles freely available online

- High visibility within the field

- Retaining the copyright to your article

Submit your next manuscript at $>$ springeropen.com 